\title{
DEMOGRAPHIC PROCESSES IN THE WESTERN PART OF THE ARMENIAN HIGHLAND* (Late XV-XIV centuries BC) ${ }^{1}$
}

\author{
Aram Kosyan
}

\begin{abstract}
The cuneiform Hittite texts of the XV-XIV centuries BC contain important information dealing with at least two different population movements happened along the Upper Euphrates region. First of these is fixed in the treaty signed between the Hittite king Tudhaliyaš II (second part of the XV century BC) and Šunaššura, king of Kizzuwatna. The second migration took place later, during the reign of Tudhaliyaš III. This second migration is of interest since in that population movement was involved a great number of people from different parts of Asia Minor. The study of several Hittite prayers compiled during the reign of Arnuwandaš I allow to assume that this second migration is definitely connected with continuous famine, hunger, plague and attacks of neighboring countries which could force the population of several regions to migrate first to Išuwa and from there to Hayaša.
\end{abstract}

Keywords: Flight of population, famine, plague, Išuwa, Hुayaša, Hatti.

In regard to the political formations of the western part of the Armenian Highland cuneiform sources of the mid-II millennium BC, particularly Hittite, contain important information according to which here are registered population movements, most probably affecting the demographic situation of the region under discussion. This information which is preserved in cuneiform texts composed during the reign of two Hittite kings has been touched upon by many scholars dealing with the history of the Hittite empire. Although these two events have been fully discussed, we should mention that currently only in regard to the background of the first text exist more or less convincing explanation. As to the second population movement, until now it lacks reliable explanation. Below we shall discuss both sources in chronological order.

\footnotetext{
${ }^{*}$ The article was submitted on November 1, 2021. The article was reviewed on November 14, 2021.

1 This study has been carried out within the framework of the grant received from the State Committee of Science, Republic of Armenia (grant N. 20TTSH-005).
} 


\section{The Flight of the population of Išuwa to Mittani}

The first source is the treaty signed between the Hittite king Tudhalyaš II and Šunaššura, the king of Kizzuwatna (second half of the XV century BC) ${ }^{1}$. In the historical prologue of the treaty is mentioned that during the Hittite campaign directed against the Upper Euphrates country of Išuwa (the province of Tsopk' of medieval Armenian sources), some groups of its population had escaped to Mittani and the king Šauštatar refused the Hittite king's demand to return these people back.

In the special literature, despite the absence of additional information, has been suggested that these refugees could have been a group of population which was closely connected to Mittani, thus hostile to the Hittites, so Šauštatar refused to hand them over to the Hittite king ${ }^{2}$. This suggestion is acceptable since after Tudhaliyaš II, during the reigns of his successor Arnuwandaš I and Šuppiluliumaš I (late XV-XIV centuries BC) in some Hittite texts are preserved the names of several chieftains of Išuwa and neighboring political entities who bore names which have good Indo-Iranian (maybe Indo-Aryan) etymology (Lupakiutta, Arziutta, Uitarna etc.) $)^{3}$. Taking into account the Indo-Iranian (Aryan) names of the kings of Mittani, indeed, one is free to propose that the population of Išuwa could have been partly Indo-Iranian ${ }^{4}$.

\section{The Flight of Hittite population to Išuwa and neighboring regions}

The second source is the treaty signed between the Hittite king Suppiluliumas I and Šattiwaza, the king of the already Hittite vassal state of Mittani. Here is mentioned about the flight of the Hittite population to Išuwa and other regions during Tudhaliyaš III, the father of the king 5 .

The text lists numerous localities, some entitled as "countries" and "cities", some as "mountains". These localities are - Gurtališša, Arawanna, Zazziša, Kalašma, Timana, Mount Hुaliwa, Mount Karna, Turmitta, Alha, Hurma, Mount

\footnotetext{
${ }^{1}$ CTH 41 and 131, edited Weidner 1923: 88ff.; Beckman 1996: 13ff. (transl.); for the ascription of the treaty to Tudhaliyaš II see Beal 1986: 432ff.; Wilhelm 1988. The treaty was compiled in two languages - Akkadian and Hittite.

2 According to T.R.Bryce, even after the conquest by Tudhaliyaš II Išuwa "remained firmly proMitannian in its loyalties" (Bryce 2005: 128).

3 The names are preserved in KUB XXIII+, an instruction/treaty addressed to the numerous chieftains of the Upper Euphrates political entities by Arnuwandaš I, the Hittite king (CTH 146). The text was first published partly by A.H. Sayce (Sayce 1930), later by V. Khachatryan (Khachatryan 1998: 87-94 [several passages]), O.R. Gurney (Gurney 1948 [complete English translation]). Complete edition of the text see in Kosyan 2006a; Reichsmuth 2011; Kosyan et al. 2018: 10-50).

${ }^{4}$ On the Indo-Iranian personal names attested in KUB XXIII 72+ and KBo XVI 42 (a letter sent to Šuppiluliumaš I by some Hittite official) see Kosyan 2006a; Kosyan 2006 b.

5 The treaty (CTH 51) was compiled in two languages - Hittite and Akkadian (edited by Weidner 1923: 2ff.; Beckman 1996: 38ff. [N.6A]) (English translation). On the passage under consideration see Kosyan 2020: 100-101.
} 
Harana, half of Tegarama, Tepurziya, Hazga, Armatana ${ }^{6}$. Then it is said that these people first had entered Išuwa and from there went to the place which was hostile to Huatti (eberti māt Ǐsuwa ina libbi nakri ašbū "beyond the land of Išuwa among the enemy") and settled down there. The text does not give the name of this hostile country (see below about the possible new habitat of these refugees).

Most of these place-names, despite the absense of convincing argumentation, has been looked near the Euphrates, to the west of the river ${ }^{7}$.

The flight of Hittite subjects to Išuwa and an unknown region to the east usually is mentioned without specification of its causes.

J.D. Hawkins and M. Weeden, taking into account the proposed localizations of some toponyms in the north-western part of Asia Minor (Arawanna and Kalašma), some in central provinces of ïatti (Durmitta, Alha,Hurma), and others in the Euphrates zone (Tegarama, Armatana and Tepurziya), concluded that some of

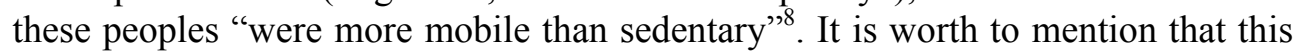
proposal could not be supported by any argument. More to say, hardly it would be possible to explain the reason of such population movement through the nature of their lifestyle, especially in the case of Arawanna and Kalašma situated in the north-western regions of Asia Minor.

Some years ago, we had suggested to explain this event in the context of the history of Asia Minor since several Hittite texts contain clear evidence for the existence of wholesale turmoil since the end of the XV century $\mathrm{BC}^{9}$. These texts tell about continuous revolts of neighboring countries against Hatti, depopulation of settlements, and raids of different countries and tribes into the Hittite territory.

Thus, in a prayer of Muršiliš II addressed to the gods of $\mathrm{Hatti}^{10}$ is mentioned the depopulation of numerous settlements during the reign of his grandfather (Tudhaliyaš III) as a result of plague and hunger. In another prayer he refers to the destructive consequences of the plague which continued for 20 years ${ }^{11}$. If one adds a much later text of Hattušiliš III (mid-XIII century BC) where it is said that during the reign of his ancestor (Tudhaliyaš III) Hatti had suffered invasions of all

\footnotetext{
${ }^{6}$ This part of the text has been published and discussed by some scholars (Forrer 1926: 35-36; Goetze 1940: 21-23; Cornelius 1958: 237-238; Krahmer 1977: 40-41 etc.). Complete edition of the text see in Kosyan 2016: 69-81.

${ }^{7}$ The discussion of these place-names see in Cornelius 1958: 239ff.; Giorgadze 1961: 174ff., for the localization see Del Monte und Tischler 1978 (by entries).

${ }^{8}$ Hawkins and Weeden 2017: 9; the same opinion is expressed by A. Altmann (Altmann 2001: 16) who suggested that this fugitive population might consist of sedentary, as well as nomadic or seminomadic components.

${ }^{9}$ Kosyan 2016: 108-113.

${ }^{10}$ KUB XIV 13 + KUB XXIII 124 (= CTH 378.IV, edited by Götze 1930: 242ff.; Lebrun 1980: 220ff.; Singer 2002: 64ff. [N.14]).

${ }^{11}$ It is said that "[People kept dying] at the time of my father, at the time of my brother, [Arnuwandaš II - A.K.], they keep on dying [in my time]. ... For twenty years now people have been dying in Hatti [in great numbers]. Hatti [has been very badly damaged] by the plague" (Singer 2002: 56 [N.10]). The same information is given in another prayer (Singer 2002: 57 [N.11]).
} 
neighboring countries (the so-called "Concentric invasion") ${ }^{12}$, then we could arrive at quite reasonable suggestion.

Thus, the texts referred to above definitely show that at least still during the last years of Arnuwandaš I Huatti had fallen into deep crisis which continued during Tudhaliyaš III, his successor. As a result, many Hittite-controlled territories were lost to invaders who attack from all directions. Probably, exactly during Tudhaliyaš III the court and central administration were forced to leave ïattušaš and establish a temporary capital in Šamuha, which was located in the east, in the Upper country. ${ }^{13}$ In one letter of the same king is mentioned the mobilization of troops organized in different regions of ïatti in order to campaign against Hुayaša ${ }^{14}$.

In the prayers addressed to the gods which were compiled during Arnuwandaš I is described a catastrophic situation in iatti. It is said that the settlements were emptied, the population had escaped, and the Kaškaean tribes were constantly invading and destroying the temples of gods, temple personnel was enslaved, and there remain nobody who could worship the gods, since the people had left their settlements ${ }^{15}$.

These sources testify that already from the end of the XV century BC Asia Minor had appeared in the period of crisis which is expressed in crop failure and plagues, neighboring countries were continuously attacking the land of Hatti, many settlements were depopulated. This situation continued until the beginning of the reign of Muršiliš II, that is about 80 years. Indeed, it is difficult to state an uninterrupted chain of famine and plague, but the effect of these negative events must have greatly influenced the lifestyle of the sedentary population.

Unfortunately, currently we lack palaeoclimatological studies dealing with this period, which could add more arguments in order to clarify the problem. Whether in our case one could speak about repeated dry or humid climatic conditions, is not clear. In both cases famine, hunger and plagues could have been true background for the situation described above.

It should be stressed that the central part of Asia Minor (the area enclosed within the River Halys-Kizllırmak) is characterized by extreme conditions for agricultural lifestyle. Despite the existence of extensive land resources, mostly fertile, climatic fluctuations could interfere into the activities of the sedentary population. The lack of precipitations, early cooling of climate (especially in August-September) and other circumstances often might have negative impact on agricultural activities ${ }^{16}$. For example, the XIII century Hittite texts point on food shortage and the import of grain from other countries, mostly Egypt ${ }^{17}$.

\footnotetext{
${ }^{12}$ KBo VI 28 + KUB XXVI 48 (CTH 88).

${ }^{13}$ Bryce 2005: 147.

${ }_{14}$ Alp 1991: 298ff.; Kosyan 2001 (transliteration and historical context).

${ }^{15}$ Singer 2002: 40ff.

${ }^{16}$ Metz 1996: 83f.

${ }^{17}$ Archi - Klengel 1980.
} 
Now let us focus on the location of countries the population of which had fled from the Hittite-controlled regions.

Only three of them are undoubtedly located in the western parts of the Armenian Highland.

Tegarama - Til-Garimmu of Neo-Assyrian sources, modern Gürün.

Zazziša - In the "Annals" of Muršiliš II is mentioned in the context of his campaign against Hayaša ${ }^{18}$. An approximate location in the east of the Hittite Upper country, in the north-west of the Armenian Highland has been proposed ${ }^{19}$.

Tepurziya - probably, is the same as ${ }^{\mathrm{KUR}}$ Teburzi attested during the northern campaigns of the Assyrian king Tukulti-Ninurta I as one of the countries of Šbaru $^{20}$.

As to Hurma, most probably it should be sought to the west of Malatya, in the fertile plain of Elbistan. ${ }^{21}$

Other countries and mountains listed in the text either had been located approximately, or their localization is doubtful yet.

Kalašma, Arawanna and Gurtališša probably lay in the north-western part of Asia Minor (in Classical Paphlagonia), or in the west ${ }^{22}$. As to Armatana, a location along the eastern or south-eastern limits of Asia Minor has been suggested ${ }^{23}$.

Even with this uncertain localization of the toponyms under discussion it becomes clear that the treaty of Šuppiluliumaš I with Šattiwaza refers to more or less mass migration of peoples to the western parts of the Armenian Highland, particularly to Išuwa and ïayaša which took place in the first half of the XIV century BC. Probably, this was not a simultaneous event, but a continuous process.

Taking into account the extensive geography of these population groups, hardly they were ethnically related. For example, the region lying to the west of the Upper Euphrates, which leads towards Halys-Kızılırmak and Kayseri at least from the late III mill. BC - early II mill. BC comprised one of the centers of Hittite statehood where during the period of Assyrian trading colonies and later period came into existence numerous small political entities, among them the above mentioned Hurma (Hurrama of Cappadocian tablets). This fact could prove that at least the population of ïurma was not related to the population of the Armenian Highland.

It seems that the next scenario is worth to suggest for the problem under discussion. Periodical outbursts of plagues and famine most probably had triggered

\footnotetext{
${ }^{18}$ The contexts see in Del Monte und Tischler 1978: 497 and Kosyan 2004: 102-103.

${ }^{19}$ To the east of Halys, towards the big bend of the Euphrates (Del Monte und Tischler 1978: 293294; Kosyan 2004: 90-91).

${ }^{20}$ Nashef 1982: 260; Harutyunyan 1985: 182.

${ }^{21}$ Del Monte und Tischler 1978: 125; M. Forlanini locates Hurma to the east of Kayseri, in the neighborhood of the town Pınarbaşi (near the River Zamantısu), and compares the name with modern Göreme (Forlanini 2007: 264-266, 278-279), that is along the road leading to Malatya.

${ }^{22}$ Del Monte und Tischler 1978: 30, 164.

${ }^{23}$ Del Monte und Tischler 1978: 38f.; Also Kosyan 2004: 40.
} 
the population of several parts of Asia Minor to leave their settlements and find refuge in the mountainous regions of the east. In this regard let us refer to the "Deeds of Šuppiluliumaš", the text compiled during the reign of Muršiliš II where is described the campaign of his father directed against Išuwa and Hुayaša with the aim to bring back the Hittite subjects ${ }^{24}$.

Unfortunately, the text which describes the campaign of the Hittite army in pursuit of Hittite subjects is damaged. Only one place-name - URU Zuhhapa which is mentioned in the context of that campaign, could give some clues for the direction of Hittite army's march. It is generally accepted that this name could be compared

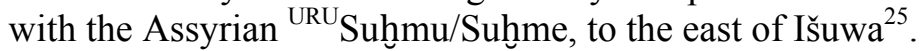

${ }_{\mathrm{H}^{\mathrm{UR}} \mathrm{SAG}}$ Laha which appears in the broken context of the same text is the only attestation of this place-name. It is said that after burning down ${ }^{\mathrm{URU}} \mathrm{Zuhhapa}$ and its environs by the Hittites the refugees escaped to iayaša. Since here the text is damaged, we are not aware whether Šuppiluliumaš I had reached Hayaša.

The existence of the Hittite subjects in Hayaša is mentioned in the final lines of the treaty signed between Šuppiluliumaš I and Hukkana, the ruler of Hayaša. Here the Hittite king demands the return of the Hittite population who to that date resided in Hayaša ${ }^{26}$. It seems that the information regarding the Hittite population residing in the east is in full accordance with that of the treaty of Šuppiluliumaš I and Šattiwaza where the Hittite population had fled to the east and resided "beyond the land of Išuwa among the enemy".

The uncertainty of the chronological correlation between two texts ("Deeds of Šuppiluliumaš" and "Treaty between Šuppiluliumaš and Hukkana") makes our reconstruction of events doubtful. It remains unknown if the treaty was compiled before that campaign or postdated it. If that campaign took place before iukkana had become the ruler of ïayaša, then we can conclude that the Hittites did not succeed to return back their population. The demand of the Hittite king to hand over the Hittite subjects makes doubtful the statement that he had achieved his goal.

In regard to the migration of the Hittite population as a consequence of the hunger, plague and attacks of neighboring states and tribes it would be worth to mention a similar event which took place in Assyria during the reign of Tiglathpileser I. ${ }^{27}$

\footnotetext{
${ }^{24}$ See Kosyan 2016: 96-97 (Fragment 25).

${ }_{25}$ Del Monte G. und J. Tischler 1978: 516; Ertem 1973: 169; Kosyan 2004: 104. But see Khachatryan 1971: 114 n.266 and Khachatryan 1998: 58 who suggests an equation with the mountains Tskhanist in Bingöl. A tentative identification of Zuhhapa with ${ }^{\text {uru }}$ Suhmu/Suhme seems

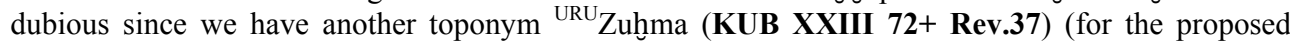
localization see Kosyan 2004: 104).

${ }^{26}$ Kosyan 2016: 40-41.

${ }^{27}$ Grayson 1975: 189; Glassner 2004: $188 f$.
} 
"IIn king Tiglath-Pileser's thirty-second year, a famine (so severe) occurred (that) peop]le ate one another's flesh; [...] Aramean 'houses' plundered ([i]h!-tabbu-tu) [the land], seized the roads, and conquered and took [many fortified cities] of Assyria. [Citizens of Assyria fled t]o the mountains of Habriuri [to save their] lives; [the Arameans] took their [.. .], their money, and their property; [Marduknadin-ahhe, king of] Babylonia, passed away ..."' This text is dated with $1082 \mathrm{BC}$.

About 150 years after this event Aššurnasirpal II, another Assyrian king tells the next: "I brought back the enfeebled Assyrians who, because of hunger (and) famine, had gone up to other lands, to the land Šubru. I settled them in the city Tušha"28.

From the text of Aššurnasirpal II it becomes evident that the Mesopotamian population who had fled to Habriuri ${ }^{29}$ at the beginning of the XI century BC moved further to the north.

The flight of the Assyrian population at the beginning of the XI century BC and their return half a century later seem to serve as good parallel to the events happened in Hittite Anatolia in the XIV century BC. In both cases the reasons for the flight of population actually are similar. The migration of the Hittite population was a response to famine(s) and hunger, combined with attacks of the Kaškaean tribes. In the case of Assyria - terrible famine and continuous attacks of the mobile Aramaean tribes; the latter also appear in difficult situation and were forced to find means of subsistence.

The background of events which took place in the XIV century BC associated with famines and plagues is not an isolated page in the history of Hittite Anatolia. Exactly with such serious problems had encountered the Hittite empire towards the end of its existence, during the last decades of the XIII century BC, which became a crucial factor for its disintegration ${ }^{30}$. This marked the beginning of a long period of the history of the Eastern Mediterranean and surrounding regions (tentatively entitled by scholars as "The XII century BC Near Eastern crisis") which lasted until the end of the XI century BC during which had left the historical scenery many states of this vast geographical area (Hatti, Mycenaean states, Ugarit etc.), others had survived but encountered significant territorial losses, possessing with far less political and economic potential (Assyria, the New kingdom of Egypt etc.) ${ }^{31}$.

\footnotetext{
${ }^{28}$ Grayson 1991: 202 (text N. A.O.101.1).

${ }^{29}$ Habriuri has been located to the north-east of modern city Irbil, the capital of Iraqi Kurdistan (Nashef 1982: 168). In this dictionary of the Middle Assyrian toponyms, it is listed under the outdated reading Kirriuri.

${ }^{30}$ We had discussed this problem in our earlier studies (Kosyan 1998a; 1998b; 1999). See also earlier and later studies (Klengel 1974; Divon 2008; Kaniewski et al. 2010 etc.).

31 Considerable number of scholars had discussed the period of crisis in Eastern Mediterranean
} (Weiss 1982; Neumann and Parpola 1989; Caubet 1989; Yon 1989 etc.). 


\section{BIBLIOGRAPHY}

Alp S. 1991: Die Hethitische Briefe aus Maşat-Höyük, Ankara.

Archi A. und H.Klengel 1980: Ein hethitischer Text über die Reorganisation des Kultes, AoF 7, 143-157.

Altman A. 2001: The Išuwa Affair in the Šattiwaza Treaty (CTH 51 obv. 10-24) Reconsidered. Ugarit-Forschungen 32, 11-21.

Bryce T.R. 2005: The Kingdom of the Hittites, Oxford (first edition 1998).

Caubet A. 1989: Reoccupation of the Syrian coast after the destruction of the "Crisis Years", in Ward W.A., Sharp Joukowsky M. (Eds.), The Crisis years: the $12^{\text {th }}$ century BC. From Beyond the Danube to the Tigris, Dubuque, 123-131.

Cornelius Fr. 1958: Geographie des Hethiterreiches, Orientalia 27, 225-251, 373-398.

Del Monte G. und J. Tischler 1978: Die Orts- und Gewässernamen der hethitischen Texte, Wiesbaden (Répertoire Géographique des Textes Cunéiformes, Bd.VI.1).

Divon Sh.A. 2008: A Survey of the Textual Evidence for "Food Shortage" from the Late Hittite Empire, in The City of Emar among the Late Bronze Age Empires History, Landscape, and Society Proceedings of the Konstanz Emar Conference, 25.-26.04. 2006 (eds. Lorenzo d'Alfonso, Yoram Cohen, and Dietrich Sürenhagen), 101-109.

Ertem H. 1973: Boğazköy metinlerinde geçen coğrafyan adları dizini, Ankara.

Forlanini M. 2007: The Offering List of KBo IV.13 (I 17'-48') to the local gods of the kingdom, known as "Sacrifice List", and the history of the formation of the early Hittite state and its initial growing beyond central Anatolia, in A. Archi, R. Francia (eds.), VI Congresso Internazionale di Ittitologia. Roma, 5-9 settembre 2005 (Studi Micenei ed Egeo Anatolici 49), Rome, 259-280.

Forrer E. 1926: Die Boghazköi-Texte in Umschrift, Bd. II, Leipzig.

Giorgadze G.G. 1961: Towards the questions of the Localization and Language Structure of Kaskaean Ethnic and Geographical names, in Peredneaziatskij sbornik I, Moscow, 161-210 (in Russian).

Glassner J.-J. 2004: Mesopotamian Chronicles, Atlanta.

Goetze A. 1940: Kizzuwatna and the Problem of Hittite Geography, New Haven.

Götze A. 1930: Die Pestgebete des Muršiliš, Kleinasiatische Forschungen 1, H.2, 161-251.

Grayson A.K. 1975: Assyrian and Babylonian Chronicles, Locust Valley, New York.

Grayson A.K. 1991: The Royal Inscriptions of Mesopotamia. Assyrian Periods / Vol. 2, Assyrian Rulers of the Third and Second Millennia BC (1114-859 BC), TorontoBuffalo-London.

Harutyunyan N.V. 1985: Toponyms of Urartu, Yerevan (in Russian).

Hawkins J.D. and Weeden M. 2017: Kizzuwatna and the Euphrates States: Kummaha, Elbistan, Malatya: Philology, in Hittite Landscape and Geography (eds. M. Weeden and L.Z. Ullmann), Leiden-Boston, 1-17.

Heinhold-Krahmer S. 1977: Arzawa. Untersuchungen zu seiner Geschichte nach den hethitischen Quellen, Heidelberg (= Texte der Hethiter 8).

Khachatryan V.N. 1971: Eastern Provinces of the Hittite empire, Yerevan (in Russian).

Khachatryan V.N. 1998: Armenia in the XV-VII centuries BC, Yerevan (in Arm.).

Kaniewski D., Paulissen E., Van Campo E., Weiss H., Otto T., Bretschneider J., Van Lerberghe K. 2010: Late second - early first millennium BC abrupt climate changes in coastal Syria and their possible significance for the history of the Eastern Mediterranean, Quaternary Research 74, 207-215. 
Klengel H. 1974: "Hungerjahre" im Hatti, AoF 1, 165-174.

Kosyan A.V. 1998a: Isuwa and Gordion in the XII-X centuries B.C. (A comparative study), Patmabanasirakan handes 3, 177-194 (in Arm., English summary).

Kosyan A.V. 1998b: The XII century B.C. Crisis. Ethnic Movements and Depopulation (discussing the problem), Lraber hasarakakan gitutyunneri 3, 45-52 (in Russian).

Kosyan A. 1999: M.t'a. XII dari merdzavoarevelyan č'gnažamə ev Haykakan Lernaškharhə (The XII Century B.C. Near Eastern Crisis and the Armenian Highland), Yerevan (In Arm., English summary).

Kosyan A. 2001: New Data about the Interrelations between the Hittite Empire and the Countries of the Armenian Highland, CPNME XX, 233-245 (in Arm., English summary).

Kosyan A.V. 2006a: An Aryan in Isuwa, Iran and the Caucasus 10/1, 1-6.

Kosyan A.V. 2006b: Arnuwandas I in the East, AJNES I, 72-97.

Kosyan A.V. 2016: The XIV century BC Interstate Treaties between the Hittite Empire and Hayasa, Yerevan (in Arm.).

Kosyan A.B. 2020: The Euphratian Contact Zone in the II Millennium BC (on the example of Isuwa CPNME XXXIII (1), Yerevan, 95-110.

Kosyan A.V., Ghazaryan R., Khanzadyan M., Martirosyan S. 2018: The XV century Hittite Cuneiform Texts about the Armenian Highland, Yerevan (in Arm.).

Lebrun R. 1980: Hymnes et prières Hittites, Louvain-la-Neuve.

Neumann J., Parpola S. 1987: Climatic change and the eleventh-tenth-century eclipse of Assyria and Babylonia. Journal of Near Eastern Studies 46, 161-182.

Reichsmuth S. 2011: Mita von Pahhuwa (CTH 146), In Hethitologie in Dresden, Bd. 35 (Hrsg. R. Fischer, D. Groddek u H. Marquardt), Wiesbaden, 109-144 (= Dresdner Beitrage zur Hethitologie).

Singer I. 2002: Hittite Prayers, Atlanta.

Weiss B. 1982: The decline of the Late Bronze Age civilization as a possible response to climate change. Climatic Change 4, 173-198.

Yon M. 1989: The End of the Kingdom of Ugarit in Ward W.A., Sharp Joukowsky M. (Eds.), The Crisis years: the 12th century BC. From Beyond the Danube to the Tigris, Dubuque, 111-122.

\section{ABBREVIATIONS}

AoF - Altorientalische Forschungen, Berlin.

CPNME - Countries and Peoples of the Near and Middle East, Yerevan.

CTH - E. Laroche, Catalogue des Textes Hittites, Paris.

KBo - Keilschrifttexte aus Boghazköy Leipzig und Berlin, 1916ff.

KUB - Keilschrifturkunden aus Boghazköy, Berlin, $1921 \mathrm{ff}$. 


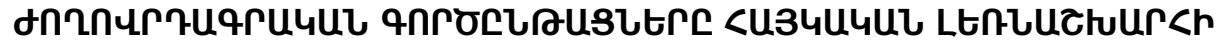

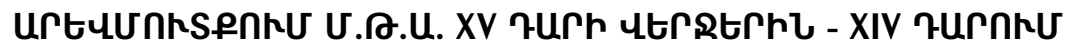

Uрuи คnuјu氏

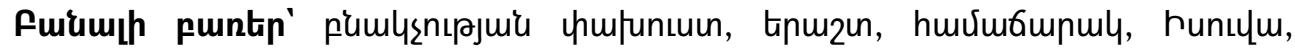
<mјшum, tumpph:

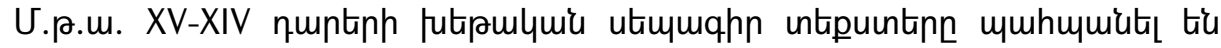

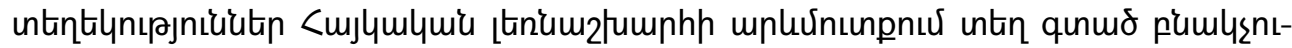

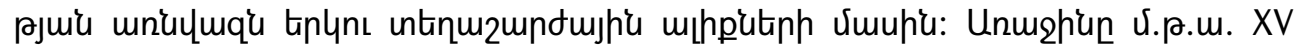

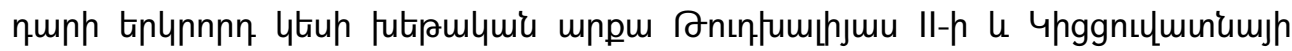

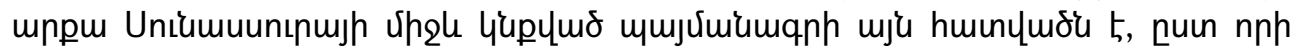

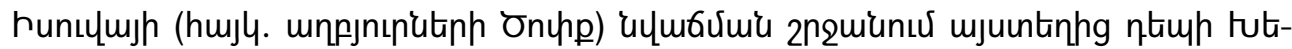

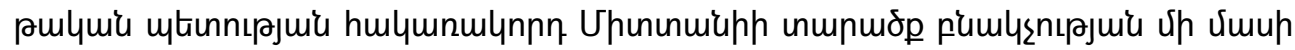

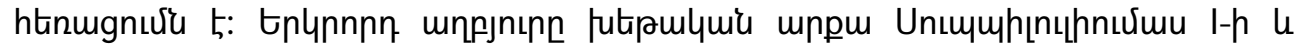

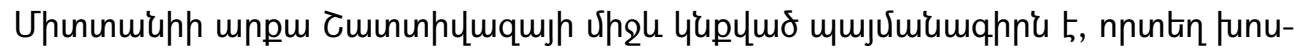

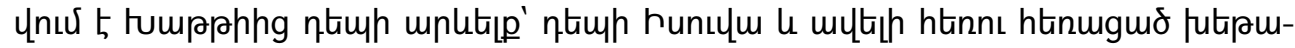

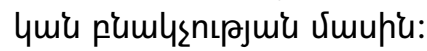

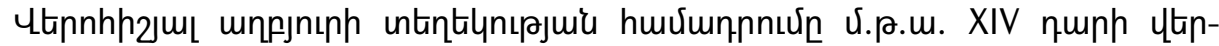

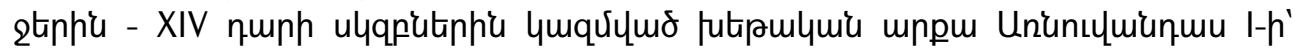

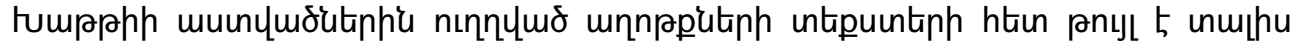

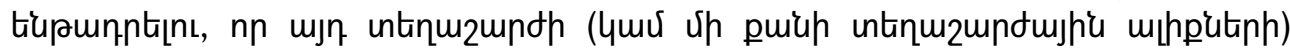

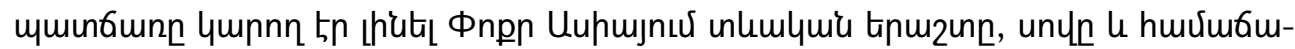

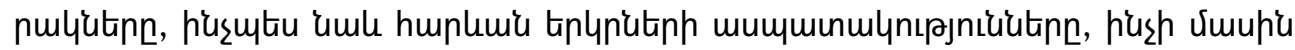

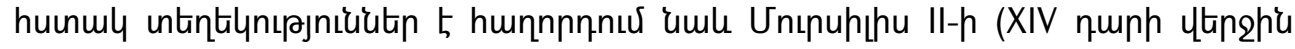
punnpn) up untpuinn:

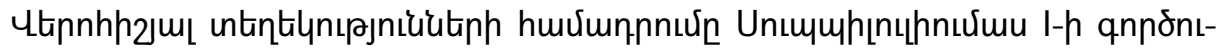

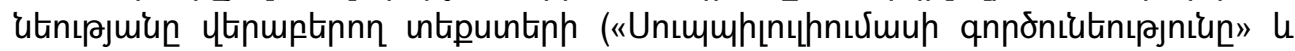

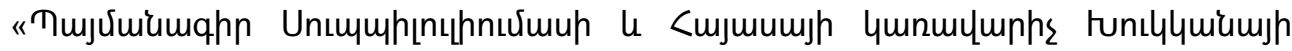

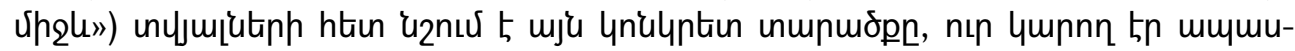

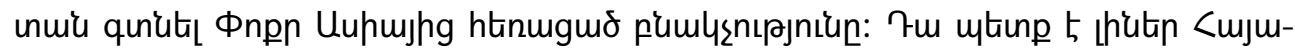

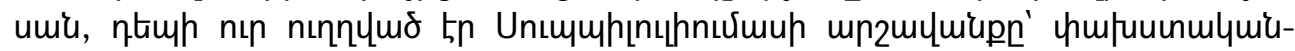

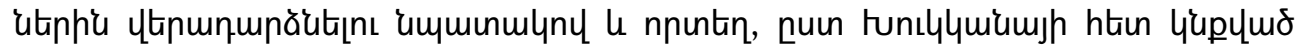

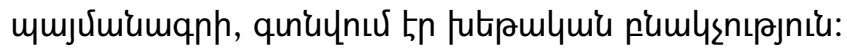

